\title{
Malerba and the Art of Story-Telling
}

The narrative inventiveness of Luigi Malerba seems to be triggered off by fairy-tale situations. His stories are rooted in the madness and cruelty of the world, solidly based on bloodthirsty games and logical perversions, propelled by the urge to outrage and provoke. Malerba is a great fabulist because he masters the whole range of transgressions, from frenzy to cruelty, from obscenity to immorality, which are the staple diet of fairy tales. It takes more sacrilegious daring to write Snow White and the Seven Dwarfs than Snow White in Pornoland.

In a famous poem Ogden Nash reminded us that children like tales, provided there is at least a bear munching a man - and they want to hear the echo of crunched human bones: "It really doesn't take much to fill their cup/All they want is for somebody to be eaten up." ${ }^{\prime \prime}$ Suitable substitutes for a banquet of human flesh: torture, dismemberment, treachery, agony, damnation, gore, butchery, child-murder, blinding, drowning, stifling, death-rattles, mass-killing. Children like a hot narrative diet. Three characters are needed to make up a fairy-tale: a story teller, a story subject, and a story listener. If the subject is a bear who eats men or a wolf who eats children (after all, the Grandmother is just a poor ersatz of dainty Little Red Riding Hood: mock duck on the wolfish menu), then one only requires a child who devours stories about animals who devour human beings, and a story-teller ready to recount those nefarious deeds. Well, Malerba is ready and willing. Zack! and off with that head. ${ }^{2}$ Zizz zuzz! and the legs of the tallish subjects of a dwarfish king are sawn, lest they should grow taller than their lord and master. ${ }^{3}$ Gulp! the blackbird swallows its favourite delicacy, an eyeball straight from a man's socket. ${ }^{4}$ Boom! a car is blown up by a fermenting pumpkin. ${ }^{5}$ Vlam! a husband throws his wife's hair into the fire, without noticing that his spouse is still attached to her locks. ${ }^{6}$ Clickety-click! the door of the cage box is locked, and the growing man is condemned to perpetual dwarfdom. ' Snatch! the friar's cowl is torn so suddenly that part of the scalp comes with it. ${ }^{8}$ Anyone appearing in a story by Malerba must expect at the very least to have all his bones 
broken. The unfortunate fellow who wants to imitate a spider's descending technique, spits from the top of a tree and then tries to lower himself hand by hand down his dribble, is quite fortunate. The curve of his saliva jet gets him forty days in hospital:' a mild sentence for a Malerbian character.

In fables (be it Puss'n Boots, Pinocchio or Hansel and Gretel), the starting element is often hunger ("argumento de grandissima urgenzia e gravezza"). ${ }^{10}$ The usual alternative is between eating and being eaten. To avoid being eaten by the lion, Carestia proceeds to eat it, mane and tail included. ${ }^{11}$ As a punishment he is locked up in a cage with the lioness, whom he promptly dispatches down his digestive tract. ${ }^{12}$ In other stories characters wait openmouthed for their food to fall down from above. When the castle of Berlocchio in the County of Tripalle is laid waste by a fire, the cats blissfully sit in the courtyard with their jaws wide open, waiting for the crisply done mice to fall from the burning windows into their feline gullets. ${ }^{13}$ This is like the happy world of Tom and Jerry (also great masters in the arts of torture and massacre). Malerba describes a human world where men behave like animals (following a model which is as old as literature itself) and an animal world in which animals behave like men (another long-standing tradition in which Malerba's most recent predecessor is the Marcel Aymé of Les Contes du chat perché). ${ }^{14}$ The common denominators of these two worlds are pain and death: man and beast suffer and perish to the infinite entertainment of writer and reader.

This is the carnal, flesh and blood, physical side of Malerba's writing, which seems predominant in his work. Malerba has actually suggested that his inspiration does not come from interiorità, his inner self, but from interiora, his innards. His range however covers far more than the flesh. He knows exactly how and when to change register, uplifting the tone in moments of rampant carnality, or dropping it down to guts' level whenever the cerebellum becomes too cumbersome. Even at the nadir of human bestiality and bestial bestiality, Malerba does not give up thought - which, according to Hamlet, makes things good or bad. The smell of a bedbug is not only a fact of life (bedbugs smell, therefore they smell), but a moral dilemma which torments the poor little thing and makes it utter interior monologues about its existential predicament. Thus parasites have a place both in the carnal novel - where fleas are made to proliferate in the uniforms of Turkish soldiers in order to heighten their aggressiveness $-;^{15}$ or in the cerebral novel, where the bug becomes an existential being who cannot tolerate the abstract idea of its own stench. ${ }^{16}$ The bug does not really object to its actual foul smell, but to the Platonic idea of 
it, just as Hamlet could not accept the abstract concept of his own inertia.

The carnal element is constantly exploited by Malerba within the context of hunger and lust. At other times, the writer uses the cerebral element in the realm of the absurd. It would be nice, useful, amusing and comforting if we could make out two rhetorical categories within the absurd, starting e.g. from Foucault's opposition of incongruous vs. heteroclite. ${ }^{17}$ Foucault quotes Borges quoting a list of the animal species in a Chinese encyclopedia: a list which to our European mind sounds outrageously absurd. Foucault then proceeds:

That passage from Borges kept me laughing a long time, though not without a certain uneasiness that I found hard to shake off. Perhaps because there arose in its wake the suspicion that there is a worse kind of disorder than that of the incongruous, the linking together of things that are inappropriate; I mean the disorder in which fragments of a large number of possible orders glitter separately in the dimension, without law or geometry, of the heteroclite; and that word should be taken in its most literal, etymological sense: in such a state, things are 'laid,' 'placed,' 'arranged' in sites so very different from one another that it is impossible to find a place of residence for them, to define a common locus beneath them all. Utopias afford consolation: although they have no real locality there is nevertheless a fantastic, untroubled region in which they are able to unfold; they open up cities with vast avenues, superbly planted gardens, countries where life is easy, even though the road to them is chimerical. Heterotopias are disturbing, probably because they secretly undermine language, because they make it impossible to name this and that, because they shatter or tangle common names, because they destroy 'syntax' in advance, and not only the syntax with which we construct sentences but also that less apparent syntax which causes words and things (next to and also opposite one another) to 'hold together.'

We could attempt to move our essay towards a direct confrontation of the texts, applying the incongrous vs. heteroclite pair to an analysis of detailed passages. I wonder whether it would be possible to imagine an opposition - or even a clash - between the world of Ionesco and the world of the Marx Brothers according to Foucault's model. Ionesco tends to strain logic by a series of jerks, forcing it to come face to face with its own inefficacy. He gives us a logical structure (in the speeches by the 'logicien' in Le Rhinocéros), or a linguistic pattern (in La Cantatrice chauve), or a taxonomy (in $\mathrm{La}$ Leçon) and then demonstrate their inapplicability, or absurdity. Ionesco's worlds are dystopias because the fragments of their reality do not hold together any longer: they are incongrous. The Marx Brothers seem to be in a different position, because with them every cerebral operation is located within the absurd. "I think therefore I 
think nonsense" ("je pense donc je déconne"). Their world, in this case, is neither a utopia nor a dystopia, but, as Foucault would put it, an heterotopia. For them the line of human behaviour, of logical sequences, of causality and probability follows an heteroclite course (we couldn't use the adjective eccentric because the very concept of centrality is absent). As an hypothesis: Ionesco's world seems to be based on a choice of the absurd as the deliberate rejection of postenlightenment rational culture. Just try to be rationalists, says Ionesco, and look what happens. On the contrary, Groucho, Chico and Harpo's crazy pranks are not a flight or refuge in the absurd, but an existential choice: they force the so-called sane people to run away lest they be taken over by the persuasive power of Marxian lunacy.

My limited culture deprives me of the admirable certainty of philosophers and logicians in this field. I only wanted to offer a working hypothesis for the examination of some of Malerba's texts according to these divisions: incongruous vs. heteroclite, Ionescoian vs. Marxian. First example: in What is this Buzzing? ${ }^{18}$ there is a syllogism whose source can be traced back to Lichtenberg and further: ${ }^{19}$ if there is a knife without a blade, and if there is a knife without a handle, then there can also be a knife without a blade and without a handle ("This is another advantage for the murderer who, if he exists, must be very clever $\left.{ }^{\prime \prime}\right){ }^{20}$ I think this a Ionescoian idea, because we have a logical structure being wrenched by a paradox. Second example: in "The adventure of a sardine" ${ }^{21}$ a man dreams that he is a sardine, but he cannot understand how come this fish reads Spanish papers, written in a foreign language. "Or perhaps it was a Spanish sardine; then everything would be more logical." 22 We are still in the field of the incongruous, and the joke about the sardine's passport could almost be signed by lonesco. Third and fourth examples: a hen believes that she would need three legs to drive a tricycle ${ }^{23}$ (for a second we readers are also caught by the paralogism; we need a moment of reflection to realise that the number of legs is impertinent). In another story which I have already quoted, a character tries to imitate a spider and spits from a tree, then jumps after his own spittle. ${ }^{24}$ Here I am not sure which category the last examples fall in. In both cases we have the Ionescoian effect: human reason leads to wrong conclusion. Yet both the hen and the man up the tree are endowed with the dignity and nobility of thinking beings precisely because their reasoning is absurd. Let us take a last example: in one short story by Malerba the hero believes that the earth is moving through space but with no one at the wheel. ${ }^{25}$ The goofy protagonist tries then to steer our planet through the universe by leaning against a wall or a 
tree and pretending to be driving. My first reaction is to imagine Harpo Marx playing the scene (maybe because of A Night in Casablanca, where Harpo is supposed to hold up the wall with one hand; but in the film the wall collapses when Harpo leaves, whereas there are no threats of cosmic clashes in the short story when Malerba's hero isn't at the wheel). Apparently, in this episode from Malerba, we are within a heterotopia ruled by Marxian laws. Or is it the opposite? Have I let myself by carried away by the luminous idea of Harpo driving the earth through space (that is Harpo as God)? One could argue that the idea of steering the world's orbit within the galaxy is nothing but an extension of Newton's scientific principle, according to which the falling apple attracts the earth just as the earth attracts the apple. Edgar Allan Poe makes numerous variations on this idea in Eureka. It is extremely difficult to classify the repertoire. Malerba in particular seems to waver between the incongrous and the heteroclite, between the Ionescoian and the Marxian. It remains true however that Malerba is a writer of the absurd, and on this point I totally disagree with Angelo Guglielmi who detects in Malerba's work a profound scientific speculation about the indeterminacy principle and an elaborate mathematical discourse (just as we used to speak of Pirandello's Einsteinian relativism in the good old days). According to Guglielmi, Malerba, when confronted with new notions of reality produced by modern science, opts for Ionesco's impertinence. ${ }^{26}$ In my opinion Malerba's scientific or parascientific culture is a pretext which only marginally affects his text. His stories are often built on an illogical proposition, not as a reaction to a logical assumption. The same argument can be used for the sociological, or populist, interpretations of his work. As a political narrator Malerba feigns commitment and opts for anarchy. As a pseudo-scientific story-teller he mimes the consciousness of indeterminacy and wallows in the absurd. There is another realm inhabited by Malerba as an individual who reads scientific books; votes for a given political party; writes for papers with certain political allegiances; has his own mind about public events; is politically active both at the national and local level. But life and creative writing are two different things.

It is often necessary to find a pretext in order to speak about an artist or a writer. An ideological label becomes then the simplest way of approach. "A treatise on the philosophy of Mirò. Philosophy! think about it!" ${ }^{27}$ sarcastically remarks Henry Miller, who identified himself with Michelangelo against the "ideational" Leonardo ${ }^{28}$ Even "The Philosophy of T.S. Eliot" is a suspect title, let alone "The Philosophy of Dante." Fortunately Malerba is a man 
of letters who uses ideas, not an ideologist who exploits literature. Furthermore, one should not assume that the essential absurdism of Malerba relegates him within the bounds of humour, privileging the comic over the serious mode. Anyone holding such an opinion should check his index-cards about the foremost writers of this century.

Malerba's predilection for the absurd is reinforced by his wideranging talent as a fabulist. He is a master of many rhetorical topoi of the fable: from the mirage ("the whole army was leaning on the side of the wind and let itself be dragged by its force": $:{ }^{29}$ a vision seen with the eyes of the mind) to the Arabian Nights paralogism (such as the vase that contains "things which are much bigger than itself ${ }^{\prime \prime} ;{ }^{30}$ from the metamorphosis of daily reality into supernatural apparition ("The face of a pretty young maid peers out of a tiny little window upstairs: it glows like an eggplant" $)^{31}$ to the rigmarole that familiarises an absurd event by rhythmic and rhymatic seduction ("Sasso quadrato e sasso tondo! Io vendo li melio sassi del mondo": 32 "Rocks square, rocks curled! I sell the best rocks in the world!'). At the summit of his art as a fabulator I would put two episodes in Le rose imperiali: the struggle between the long-winded and the short-winded soap-bubble-blowers, ${ }^{33}$ and the construction of houses whose walls are made of opposite winds. ${ }^{34}$

Malerba makes a masterly use of literal-mindedness which, by breaking down the barriers between things and words, gives ample lee-way to his phantasy. Let us take a banal example: the one-eyed man "sees everything cut in half", ${ }^{35}$ therefore he can only see half an apple, half a woman, half a pig. But there can be definite advantages to this: he sees only half of the robber who is chasing him; half of the wolf who is trying to devour him; half of the storm, and so on. ${ }^{36}$ The one-eyed man has only one eye, therefore he sees everything in half, therefore. . . . Literalism leads to paralogism. In order to take words seriously, one is forced to take things lightly. Words, both in the fairy-tale world of Le Rose imperiali or Storie dell'anno mille, or in the crude world of $I l$ Protagonista ${ }^{37}$ or Il Pataffio, vouch for an otherwise shifty and deceptive reality. In what sense for example is the Bar Centrale of Pavona really central? "See here the Center of the world is not around these parts. ${ }^{\prime \prime 3}$

Words are free as they can only ever be in the world of fable and nonsense, and the same time they are prisoners of their lexical, phonetic, semantic, onomatopoeic responsability. "Then I'll tell you, we do a bit of everything. A bit of everything? What kind of everything do you do?" ${ }^{\prime 39}$ Or "And what shall we do now?" 'We'll wait.' 'For whom?' 'For someone.' 'Is this someone strong enough?" "40 
An Italian critic, Giuliano Gramigna, has suggested that Malerba's characters ignore the existence of metaphor because they are fully integrated in their rhetorical universe. ${ }^{41}$ This ametaphorical world exists literally, as if the ancient fracture between words and things had never been invented; and its inhabitants are often the terrified victims of this literalness. The philatelist in The Serpent is distressed when Furio Stella, his singing teacher, tells him that he is somewhere between a baritone and a tenor. "I didn't like that. I've always been for precision. . . " +2 In other words, he wants to be the one or the other. The intermediate position frightens him because it does not endow him with a definition, which in turn would allow him the respectability of a profession, or the legitimacy of a clear role. But many of Malerba's characters, human and animal, long to escape from their fixed abode in the taxonomy of their society in order to find a new identity. A hen tries to be a crane; ${ }^{43}$ a cow relentlessly attempts to lift three legs because she wants to look like a flamingo: ${ }^{44}$ a pig looks so much like a horse that it is taken for a horse, while there is a horse so much like a pig that it is called a pig. ${ }^{45}$ In short, Adam caused great confusion by giving names to Malerba's animals. Although we know that a rose called by any other name would smell just as sweet, the frantic exchange of onomastic certificates and identity papers becomes not only contagious, but frightening. The opposite also occurs: people reinforce their names by doubling them lest they would lose their identity by the roadside. This is the case of Giuseppe called Giuseppe, the one and multiple protagonist of What is this Buzzing? In Il Pataffio we have " 'Torta de mele!' 'Crostate de fichi!' 'Castagnaccio coi pinoli!' 'Pandespagna dorato!' 'Torta sambugata!' 'Torta francesca de ricotta pecorina!'"46: a litany of sweets and desserts. This can be compared with the burst of warming up words in Storie dell'anno mille: "In order to warm up they cried out all the warm words that came to their mind: sun fire oven cool chimney smoke summer sulphur fever desert hell pyre. ${ }^{\prime 47}$ Here the dividing line which in Western culture separates the sign from the referent is shaking. Michel Foucault has studied the problem of a coupure épistémologique, starting from Magritte's painting representing a pipe with the caption "Ceci n'est pas une pipe." 48 But he could just as well have used the example of Pinocchio, who tries to cook his dinner in a painted pot simmering on a painted fire; or of Malerba, who wants to "feed us with the very name of meat," as Kate says in The Taming of the Shrew. ${ }^{.9}$ The man who sells words, be they sweet or bitter, spicy or mild, does not solve psychological or economical problems because verbal nourishment leads to literal starvation. Yet sounds can pacify the 
pangs of hunger, help to perform the ritual of a meal. "The arse is always a great thing to see" Malerba says, even if you don't touch it or know it. . $^{50}$ "Torta ungaresca de pome cotogne!" is still a sweet sound, even if the flatus vocis is not edible. Malerba is a poet of verbal salivation, a psalmist of God's gastronomical bonanza (see the dream of Berlocchio in Il Pataffio). ${ }^{51}$

Fairy tale characters are often forced to choose between two opposite alternatives: they can either accept the world of things, or opt for the world of words. If the character chooses the former, he must then literally wear the real hide of a real ass in order to become one. If he is hungry, he must find a house made of marzipan and eat it. He must enter the lion's cage and eat the whole beast, skin, mane and everything ${ }^{52}$ If he/she goes to sleep, it is for a thousand years. The referents ass, food, lion, sleep, cannot be exorcised or tamed by the sound of the words which denote them. The ass must be put on, the food and the lion must be eaten, sleep must be slept.

On the other hand we have Puss'n Boots who overthrows the order of things and facts (the reality of his master's poverty) by inventing a parallel world made solely of words (the fiction of his master's riches). Or characters like Ali Baba who can open the door to the cavern with magic words. This is the realm where one can invent a verbal patisserie, or a horse called pig, or a house made of wind. Sounds and words and breaths: all flow through the air with extreme ease. Even speeches obey "the law of gravity like all the things of this Earth," 53 but the word "takes flight" when it is all by itself, and then "the following word cannot be linked to the preceding one (which has flown away) and, if the window is open, it flies away too." 54

There are two basic themes in Malerba's stories and novels: flight and cannibalism. In a way, one could say that cannibalism stands for the world of things, and flight for the world of words. Man, starting from somewhere between heaven and hell, can chose to take off and fly, or to fall down and eat (his own kind in particular).

Man is like a rhinoceros who wants to fly: "I run through the countryside back and forth with no effort, free and solitary as a rhinoceros. With the difference that he weighs a ton or so and I'm light as air." ${ }^{\prime 5}$ But the best way of flying is like an airplane on the tarmac: "I began to run when I was on the taxi-way, I rose from the midpoint of the runway in a perfect take-off." ${ }^{156}$ And in What is this Buzzing?: "I would have flown on high in the Heavens like an airplane I enjoy flying." ${ }^{57}$ To fly like a bird might be equally pleasant, but it is difficult because "birds fly, but I set out on foot towards the Railway Station. ${ }^{\prime \prime 58}$ Human flight must always differ 
from that of natural or mechanical birds. It is often rather awkward, "breaking on my heels ... my jacket swollen by the wind ..." ${ }^{\prime 59}$ propelled by a gust of wind blowing through one's clothes, ${ }^{60}$ "his shirt swelling like a sail." ${ }^{161}$ Sometimes men fly like new-hatched birds trying their wings: Giuseppe called Giuseppe ("the fly-killer") "plunged down from the bridge on his black bicycle: he seemed to be flying in the air the way birds fly when they start flying. ${ }^{\prime 62}$ But on other occasions they fly like decrepit birds ready for an Old Fowls Home: "How do very old birds manage to take off? Landing is easier but the take-off requires all the engine's powers. ${ }^{\prime 63}$

Several social classes and professional categories are refractory to the art of flying. "Can a stamp-dealer fly?"64 "A stamp-dealer cannot fly. Nobody has ever heard of a stamp-dealer taking flight. A beggar can't fly either. . . . Police Inspectors cannot fly. . . . And can a cannibal fly?"'65 They are too earthbound; their feet are "heavy, planted heavily on the earth." vourable state for flying. Yet men still find it difficult because their flight is all but dream-like. Gaston Bachelard, the highest authority on oneiric aviation, once laid out a few rules for people wishing to dream a pleasant flight: kick the ground with your heels, and off you go like a rocket, another Superman or winged-heeled Mercury (no need in dreams of shoulder-wings, neither angel's nor bird's). Only once, in the "ugly mixed-up dream" ${ }^{\prime 67}$ of The Serpent, does Malerba approach this dream perfection: "I passed beneath the arches of the bridge. . . I I volplaned down over the Old City. . . . I wheeled around the spire of the Duomo, over the smoke-stacks of the Barilla factory." ${ }^{168}$ Elsewhere we find different kinds of flight, as when Berlocchio dreams wide awake, shutting his hands tightly over his eyes and ears, and is taken "upwards over the skies." ${ }^{\circ 9} \mathrm{We}$ also have the winged flight of angels who "flutter, ${ }^{\prime \prime 70}$ or the headlong dive, as Bernarda's in her husband's dream, when "she flies down into the yard." ${ }^{\prime 1}$ The sentinels who are shoved down from the battlements "flap their arms and legs as they try to fly; falling in the void, they still beat the air with their arms as if they were wings." ${ }^{2}$ Alas, for want of having read Bachelard, they are smashed to pieces when they hit the ground. "Volare non volant, ${ }^{\prime \prime 7}$ is the solemn comment of Frate Cappuccio.

To sum up, the best way to fly is to be a bird, even if only a metaphorical one. After being kissed by Miriam, the stamp-dealer in The Serpent is "sure he [can] fly, free from the laws of gravity." "74 So he climbs a wall and tries unsuccessfully to take off. But when the bird (in Italian uccello, which is also the slang word for the penis) enters the scene as the protagonist of the novel by the same 
name, we are in a different world. The protagonist, who belongs to a radio-buff called Capoccia, claims he "would like to soar higher and higher," ready to glide over the roofs of Rome and spit on the Obelisks of the Eternal City, his rivals. ${ }^{75}$ The climax comes when the action of the non-metaphoric bird (to fly) and the action of the metaphoric bird (to have coitus) combine. The protagonist falls in love with a mummy of the Vatican Museum; while dreaming of possessing her timeless body, he whispers words of love to her: "I know that they have removed your entrails and put them in an urn. Therefore inside you are empty: as if you were purified. I have always dreamt of a young lady who is empty inside, so that the bird can fly as he wishes. . ." Beyond the words that fly away one after the other, beyond music that gives "the distinct sensation of flying, ${ }^{\prime \prime 7}$ the supreme flier is flying his flight, in an experience which joins vitality and mortality, the joy of life and the fear of death. It is the meeting point between the psychology of Freud and the theories of his reverse ego, Dürf. Sigmund Freud is known to everyone; he is the Viennese psychologist who demonstrated that sexual phantasies, when repressed, produce as a substitute dreams and visions of flight. Ludwig Dürf is not quite so well-known. The poet and wit Robert Conquest cited in an issue of the New Statesman ${ }^{78}$ a little known contribution by Dürf in the Acta Lingui stica Cracoviensa. Dürf maintains that, among the people who are not sexually repressed, the pattern is inverted: their sexual dreams and phantasies are a sublimated form of their repressed desire to fly (in some specific cases, to become a pilot). He then proceeds to analyse Lady Chatterley's Lover as an example of such a transfer, since the endless images of pricks and kicks, of cunts and rants, of screwing in the rain with flowers plaited in each other's pubic hair, just stand for Lawrence's aeronautical libido. The novel clearly illustrates the author's deep desire to emulate his cousin by marriage, the German flying ace Baron von Richtofen (a complex which Lawrence actually shares with Snoopy). Symbols, as Bachelard taught us, work both ways (else, what sort of second rate symbols would they be?). Thus for Malerba the sexually repressed writer dreams of flying, and the aviationally repressed novelist dreams of sex. Both these denizens of Signor Luigi Malerba's body and psyche eventually meet inside the Vatican mummy.

Malerba is a fabulist by vocation and a story-teller by profession. In this latter capacity, he proves to be a master of pace, sensing exactly when to accelerate, just before the bend, when the narration must be pushed forward so as to get the strongest abrasive contact between story and reader. Let us take a splendid example of this skill in Boccaccio: 
'Come on then,' Bruno replied. 'But I swear to God that I won't fall for any more of Calandrino's tricks. If he were close to me as he's been all morning, I'd give him such a rap on the heels with this pebble that he wouldn't forget this little hoax of his for the best part of a month.' No sooner were the words out of his mouth than he took aim and caught Calandrino squarely on the heel with the pebble, whereupon Calandrino grimacing with pain, jerked his foot high in the air and began to puff and gasp for breath. But he nonetheless managed to hold his tongue, and continued on his way. ${ }^{79}$

This is a text-book example of dramatic irony, with one character ignoring what the other character and the reader know. Calandrino does not know that Bruno knows that Calandrino is not invisible. But what we actually enjoy in the passage is the effect of simultaneity: the pace of the action is matched by the pace of the narrative. The process reminds us of balloons in a comic strip: 'Wham,' 'Zack' or 'Swing' are effective because they are as short as the blow, the crash, the punch they convey.

Few contemporary novelists know this art of pushing down on the pedal of narrative in order to accelerate the reading tempo as the tale moves towards a climax. In our century one of the great specialists of this technique is Henry Miller (although the critics and the public usually refer to him for less technical reasons). I shall just quote a short example from Tropic of Cancer: "In Russia it often happens that a man sleeps with a woman without touching her. They can go on that way for weeks and weeks and never think anything about it. Until Paff: once he touches her . . Paff! Paff! and after that it is Paff! Paff! Paff!" 80 The narrative shifts into fourth gear and the discourse describing the arousal of lust has the same urgency as the lust described. Miller is unsurpassed in this art. Not even Niki Lauda ever took a curve at such a speed.

Malerba too knows how to give a sudden spin to his narration, hurling it forward at a frenzied pace. When her husband Baldassare comes home, Cesira, the peasant woman descri' ed as 'stramagnacazzi' (a greedy consumer of male organs),

the window and pulls down his pants. ${ }^{\prime \prime 1}$ The rapidity of the actior. „ parallel to the rapidity of the description. In the scene of the fair, in Il Pataffio, the mountebank arrives with flax and gasoline, inserts a cannula into his sphincter "and together with the brass sound of his fart he expels a huge blaze which lightens the whole yard of the castle." ${ }^{\prime \prime 2}$ The next moment we see him behind a tent, "sitting in a bucket full of cold water." ${ }^{\prime 83}$ The speed forces both scenes to be superimposed in the reader's mind.

Malerba is in fact at ease in all kinds of narrative paces: flat on the accelerator (the 'mental' singing in The Serpent; the episode of 
Dido and Aeneas in What is this Buzzing?; Berlocchio falling in love with a donkey in $I l$ Pataffio); on the innumerable curves of a Montecarlo Rally (the 'mysterious dream' in The Serpent; the first pages of What is this Buzzing?; the equivocation between Elisabella and Isabetta in $I l$ Protagonista); the unexpected shifting of gear or direction (such as the ending of 'Le oche volano' in La scoperta dell'alfabeto; ${ }^{84}$ Elisabella's arrival in Il Protagonista; the scene when Migone catches Bernarda and Frate Cappuccio in flagrante in $I l$ Pataffio). There are also magnificent examples of a slow start followed by abrupt acceleration. When Millemosche is invited to the first and biggest banquet of his famished life, he undoes his shirt at the neck, takes off his crown, then gingerly picks a black olive and places it gently in his mouth. His two partners do the same and, as they don't know where to spit the stone, they swallow it with the rest. The feast begins cautiously, slowly, in a sluggish narrative tempo; then frenzy takes over: "He clasps a turkey's leg .... an enormous chunk of meat is torn to pieces and devoured in three bites as strong as those of a pair of pliers ... he stuffs his mouth with all sort of food. . . ." ${ }^{\prime 85}$

I have made extensive quotations in order to show the generosity of Malerba's art, the richness of his narrative, the ductility of his style. I also wanted to illustrate his mastery over a great variety of technical devices, partly borrowed from the cinema, which is his first activity (in time and in quantity: not necessarily in quality). Malerba takes and gives great pleasure in the act of story-telling, but sometimes he takes an antagonistic position toward the act of narration itself. Malerba's relation to his own writing - or to writing in general - is extremely ambiguous. This however should be the subject of another article.

\section{University of East Anglia}

\section{NOTES}

1 In "Don't cry, Darling, it's Blood all right," from Ogden Nash, Parents keep out (London, 1962).

2 Most of the stories in Le rose imperiali (Milano, 1974) end with a beheading.

3 Luigi Malerba and Tonino Guerra, Storie dell'anno mille (Milano, 1969), p. 185.

4 Ibid., p. 78.

5 L. Malerba, The Serpent, translated from the Italian by William Weaver (London, 1968), p.99.

6 Storie dell'anno mille, p. 194.

7 lbid., p. 185.

8 Ibid., p. 29.

9 L. Malerba, Storiette, (Torino, 1977), p.17-18.

10 L. Malerba, Il Pataffio, (Milano, 1978), p. 63.

11 Storie dell'anno mille, p. 161. 
12 Ibid., p. 170.

13 Il Pataffio, p. 41.

14 Marcel Aymé, Les Contes du chat perché (Paris, 1939).

15 Il Pataffio, p. 142, but see also L. Malerba, Il Protagonista, (Milano, 1973), p. 64.

16 Storiette, p. 63.

17 Michel Foucault, Les mots et les choses: Une archéologie des sciences humaines (Paris, 1966), p.9. Trans. in English as The Order of Things, Archaeology of the Human Sciences (London, 1974).

18 L. Malerba, What is this Buzzing? Do you hear it too?, trans. by William Weaver (New York, 1969).

19 A knife without a handle and without a blade is already to be found among the aphorisms of Georg Christoph Lichtenberg, Aphorismen, ed. A. Leitzmann (Berlin, 1902-1908). But the Quellenforschung has discovered another knife of this sort in a Almanack of the early 18th century. This in turn must have derived from a preceding source, and so on. The knife with a handle and with a blade, and the knife without handle and without blade must have appeared simultaneously at the beginning of time.

20 What is this Buzzing?, p. 32.

21 L. Malerba, Dopo il pescecane (Milano, 1979), pp. 93-101.

22 Ibid., p. 94. Italics are mine.

23 L. Malerba, Le galline pensierose (Torino, 1980), story no. 23.

24 Storiette, pp. 17-18.

25 Dopo il pescecane, pp. 39-45.

26 Angelo Guglielmi, "Le astuzie di Malerba," in Tempo presente (August 1968), 8285.

27 Henry Miller, Tropic of Cancer (London, 1965), p. 65.

28 Henry Miller, Black Spring (London, 1965), p. 58.

29 Le rose imperiali, p. 64.

30 Ibid., p. 114.

31 Il Pataffio, p. 49.

32 Ibid., p. 65.

33 Le rose imperiali, pp. 17-26.

34 Ibid., pp. 45-51.

35 Storie dell'anno mille, p. 79.

36 Ibid.

37 Luigi Malerba, Il Protagonista (Milano, 1973)

38 What is this Buzzing?, p. 168.

39 Ibid., p. 132.

40 Storie dell'anno mille, p. 210.

41 Preface to Storie dell'anno mille.

42 The Serpent, p. 13.

43 Le galline pensierose, no. 18.

44 Storiette, p. 39.

45 Ibid., p. 5.

46 Il Pataffio, p. 69.

47 Storie dell'anno mille, p. 174.

48 Michel Foucault, Ceci n'est pas une pipe. Deux lettres et quatre dessins de René Magritte (Montpellier, 1973).

49 W. Shakespeare, The Taming of the Shrew, IV. iii. 32.

50 Il Pataffio, p. 68.

51 Ibid., p. 60.

52 Storie dell'anno mille, p. 161.

53 The Serpent, p. 165.

54 Ibid., p. 175.

55 What is this Buzzing?, p. 197.

56 The Serpent, p. 102.

57 What is this Buzzing?, p. 191.

58 The Serpent, p. 5. 
59 Ibid., p. 112.

60 Ibid., p. 102.

61 Ibid., p. 144.

62 What is this Buzzing?, p. 182.

63 Ibid., p. 166.

64 The Serpent, p. 46.

65 Ibid., p. 172.

66 Ibid., p. 47.

67 Ibid., p. 100.

68 lbid., pp. 102-03.

69 Il Pataffio, p. 60.

70 Ibid., p. 92.

71 Ibid. p. 92.

72 lbid., p. 29.

73 Ibid., p. 30.

74 The Serpent, p. 31.

75 Il Protagonista, p. 30.

76 Ibid., p. 160.

77 The Serpent, p. 17.

78 Robert Conquest, "Lady Chatterley's Lover in the Light of Durfian Psychology", in New Statesman, (22 \& 29 December 1978), 863-64.

79 G. Boccaccio, Decameron, Trans. with an introduction by G.H. McWilliam (Harmondsworth, 1972),VII. 3, p. 601.

80 Tropic of Cancer, p. 236.

81 ll Pataffio, p. 73.

82 Ibid., p. 69.

83 Ibid.p. 69.

84 L. Malerba, La scoperta dell'al fabeto (Milano, 1963).

85 Storie dell'anno mille, pp. 180-81. 